\title{
STRUKTURA KAPITAŁU A POZIOM RENTOWNOŚCI SPÓŁEK KAPITAŁOWYCH NA PRZYKŁADZIE SEKTORA BUDOWLANEGO
}

\author{
Aneta Kalisiak \\ Katedra Finansów \\ Szkoła Główna Gospodarstwa Wiejskiego w Warszawie
}

\begin{abstract}
Abstrakt. Celem prowadzonych badań była identyfikacja wzajemnych zależności pomiędzy udziałem zadłużenia w strukturze pasywów a poziomem wskaźników rentowności. Badanie przeprowadzono dla przedsiębiorstw sektora budowlanego notowanych na Giełdzie Papierów Wartościowych w Warszawie w latach 2011-2015. Przedsiębiorstwa o niższym poziomie zadłużenia wykazywały brak istotnej statystycznie korelacji pomiędzy wskaźnikami zadłużenia a rentownością spółek. W grupie przedsiębiorstw o wyższym poziomie ogólnego zadłużenia wystąpiła istotna statystycznie korelacja między wskaźnikiem ogólnego zadłużenia a rentownością aktywów, sprzedaży oraz wskaźnikiem operacyjnym rentowności sprzedaży.
\end{abstract}

Słowa kluczowe: struktura kapitału, rentowność, spółki budowlane, rynek kapitałowy

\section{WSTĘP}

Lata 2011-2015 stanowiły dla branży budowlanej w Polsce istotny, zróżnicowany oraz pełen przemian okres. Dodatkowo, w 2012 roku organizowane były w Polsce mistrzostwa UEFA 2012, które wymagały zamknięcia dużych projektów inwestycyjnych, co skutkowało pogorszeniem wyników branży w latach 2012-2013. W 2013 roku odnotowano znaczne zmniejszenie przychodów spółek budowlanych. Jednak w odróżnieniu od roku poprzedniego, osiągane przez nie wyniki operacyjne oraz netto były na znacznie wyższym poziomie. Stopniowa 
poprawa sytuacji finansowej znalazła odzwierciedlenie we wzroście kapitalizacji spółek budowlanych notowanych na Giełdzie Papierów Wartościowych (GPW) w Warszawie, których wartość poprawiła się o 58\% w stosunku do roku poprzedniego [Raport Polskie ... 2013]. Po okresie spadku przychodów oraz rentowności w latach 2012-2013 branża budowlana przeżyła w latach 2014-2015 niewielkie ożywienie. W 2014 roku nastąpiła zmiana finansowej perspektywy unijnej. Ponadto, w 2014 roku nastąpiło odwrócenie tendencji spadkowej na rynku budowlanym. Obserwowany był znaczny wzrost przychodów spółek skorelowany ze wzrostem wyniku na poziomie działalności operacyjnej i wyniku finansowego netto. Kapitalizacja największych spółek notowanych na warszawskim parkiecie w 2014 roku była nieznacznie wyższa w porównaniu do 2013 roku. Głównym czynnikiem, który wpłynął na odwrócenie spadkowego trendu przychodów oraz rentowności, było zakończeniu nierentownych kontraktów drogowych. Miały one wpływ na wyniki większości spółek w poprzednich latach [Raport Polskie... 2015]. W 2015 roku obserwowany był dalszy wzrost przychodów skorelowany ze wzrostem wyniku z działalności operacyjnej oraz wyniku finansowego netto. Kapitalizacja największych spółek budowlanych notowanych na GPW w Warszawie była znacznie wyższa niż w 2014 roku. Ciągły wzrost przychodów oraz rentowności branży był związany z poprawą koniunktury gospodarczej w Polsce. Pomimo obserwowanego wzrostu, w 2015 roku nastąpiło znaczne wyhamowanie produkcji budowalnej. Wynikało to z przesunięcia kluczowych projektów infrastrukturalnych realizowanych w ramach nowej perspektywy finansowej na lata 2017 i 2018 [ Raport Polskie... 2016].

Celem artykułu jest poznanie zależności zachodzących między strukturą kapitału (mierzoną poziomem zadłużenia) a wielkością wskaźników rentowności aktywów (ROA), kapitału własnego (ROE) i sprzedaży (ROS i ROS operacyjne). Wszystkie teorie struktury kapitału wskazują na istnienie takiego związku, jednak wyniki badań dotyczące tej zależności są zróżnicowane.

\section{PRZEGLĄD LITERATURY}

Problematyka kształtowania struktury kapitału to zagadnienie będące przedmiot zainteresowania wielu teoretyków i praktyków badających finanse przedsiębiorstw. Posiadanie odpowiednich zasobów finansowych jest niezbędne do rozpoczęcia działalności gospodarczej i dalszego funkcjonowania na rynku. Określona ich wielkość oraz odpowiednia struktura stanowi podstawę do rozwoju Barburski 2016, s. 27]. Niewłaściwa struktura kapitału wywiera wpływ na jego koszt oraz może prowadzić do powstawania trudności finansowych [Franc 2003, s. 25]. Struktura kapitału jest uwarunkowana wieloma różnorodnymi czynnikami. Przedsiębiorstwo nie ma stałej optymalnej struktury kapitału. Zmiany w sytuacji 
finansowej podmiotu i otoczeniu rynkowym, w którym funkcjonuje, sprawiają, że zmienia się bilans korzyści i kosztów związanych z zadłużeniem przedsiębiorstwa [Duliniec 2015, s. 75]. Najistotniejszym problemem związanym z kształtowaniem struktury kapitału jest ustalenie odpowiednich proporcji między kapitałem własnym i obcym [Bereżnicka, Pawlonka 2014, s. 138].

Kapitał własny jest jedną z ważniejszych kategorii finansowych. Jest kluczowym funduszem, którego gromadzenie, przeznaczenie na założenie oraz trwałe prowadzenie działalności gospodarczej, a także efektywne lokowanie można uznać za podstawowe warunki powstania i realizacji wielu decyzji o charakterze operacyjnym, inwestycyjnym i finansowym [Sajnóg 2016, s. 92]. Pomimo ważnej roli, którą pełni kapitał własny, najczęściej jest niewystarczający do finansowania działalności. Jest on zatem uzupełniany zaciąganymi zobowiązaniami, które obciążone są oprocentowaniem. Zaciąganie zobowiązań stwarza dla przedsiębiorstwa ryzyko niewypłacalności, a w przypadku wystąpienia trudności finansowych naraża na ponoszenie dodatkowych kosztów. Finansowanie z kapitału obcego niesie korzyści podatkowe, które wpływają na spadek efektywnego kosztu kapitału obcego [Duliniec 2007, s. 82-83].

W literaturze wskazuje się na dwa podstawowe podejścia do ustalania struktury kapitału. Pierwsze to podejście statyczne, a drugie - dynamiczne. Podejście statyczne rozwijane było przez F. Modiglianiego i M.H. Millera [Modigliani, Miller 1958, s. 261-297]. Uwzględniając występowanie podatków na rynku, zauważyli oni powstanie tzw. odsetkowej tarczy podatkowej. Optymalna struktura kapitałowa była osiągana przy pełnym wykorzystaniu długu i zerowym kapitale własnym [Białek-Jaworska, Nehrebecka 2015, s. 31]. Włączenie do teorii struktury kapitału zjawiska asymetrii informacji pozwoliło na skonstruowanie dwóch dynamicznych teorii struktury kapitału: teorii hierarchii źródeł finansowania oraz jej uzupełnienia - teorii sygnalizacji [Pawlonka 2016, s. 59].

G. Donaldson zauważył, że firmy finansują się według pewnej hierarchii źródeł finansowania. Teoria określa kolejność w korzystaniu ze źródeł finansowania na podstawie preferencji zarządzających spółkami. Jako pierwszy wykorzystywany jest wewnętrzny kapitał własny. W drugiej kolejności, jeśli zajdzie taka potrzeba, emitowane są dłużne papiery wartościowe, a na końcu akcje [Donaldson 1961]. Preferencje zarządzających przy doborze kapitału obcego zależą od jego pochodzenia, w podziale na wewnętrzny i zewnętrzny [Mądra 2008, s. 172]. Kierownictwo chętniej korzysta z funduszy wewnętrznych firmy, bowiem w przypadku pozyskiwania kapitału wśród innych inwestorów jest zmuszone poddać się dyscyplinie i regułom rynku kapitałowego [Nawrot 2007, s. 21]. Zakładając, że przedsiębiorstwa preferują finansowanie wewnętrzne od zadłużania się, rentowność firmy zazwyczaj jest odwrotnie proporcjonalna do jej zadłużenia [Gajdka 2002, s. 298]. 
Teoria sygnalizacji zapoczątkowana została badaniami S.A. Rossa [Ross 1977]. Określa ona reakcje rynku kapitałowego na wybór określonej struktury kapitału przez spółkę. Wybór ten stanowi sygnał dla inwestorów. Menedżerowie spółek z monopolistycznym dostępem do pełnej informacji o przedsiębiorstwie wykorzystują wskaźnik struktury kapitału do przesłania na rynek informacji o jego stanie [Jerzemowska, Hajduk 2015, s. 47]. Wysyłane informacje określa się jako „dobre sygnały” lub „złe sygnały” [Duliniec 2001, s. 135-136]. Decyzje wpływające na zwiększenie udziału długu w kapitale spółki są odbierane przez inwestorów jako dobry sygnał. Ceny akcji spółki znajdujące się w obrocie rosną. Wzrost zadłużenia jest odczytywany przez inwestorów jako zapowiedź przyszłych stabilnych przepływów pieniężnych netto, które umożliwią spłatę zaciągniętego zadłużenia bez zagrożenia utraty płynności finansowej spółki. Na tej podstawie rysuje się dodatnia zależność pomiędzy rentownością przedsiębiorstwa a poziomem jego zadłużenia [Jerzemowska, Hajduk 2015, s. 47].

\section{METODYKA BADAŃ}

Badanie dotyczące zależności rentowności przedsiębiorstwa od struktury kapitału spółek kapitałowych przeprowadzono na przedsiębiorstwach sektora budowlanego notowanych na Giełdzie Papierów Wartościowych w Warszawie w latach 2011-2015. Dane do analizy pozyskano z bazy EMIS dla 34 spółek. Z badania wyeliminowano okresy, dla których dane o badanych przedsiębiorstwach były niedostępne. Ponadto, w danym roku wykluczono spółki, w których toczyły się postępowania upadłościowe. Cała próba badawcza składała się zatem ze 156 rekordów.

Jako kryterium klasyfikowania przedsiębiorstw przyjęto medianę wskaźnika ogólnego zadłużenia obliczonego jako relacja zobowiązań ogółem do pasywów ogółem. Analiza zadłużenia spółki pozwala, m.in. na ocenę jej polityki finansowej w kwestii struktury kapitału. Przyjęcie mediany wskaźnika ogólnego zadłużenia pozwoliło na pogrupowanie badanych przedsiębiorstw na mniej (grupa 1) i bardziej (grupa 2) zadłużone. Przedsiębiorstwa, dla których wskaźnik ogólnego zadłużenia w danym roku osiągnął poziom poniżej mediany, zaliczono do grupy 1 , zaś przedsiębiorstwa, dla których wskaźnik ogólnego zadłużenia osiągnął w badanym roku wielkości powyżej mediany, przyporządkowano do grupy 2 .

Dla wskaźnika struktury kapitału oraz wykorzystanych innych wybranych wskaźników obliczono średnie arytmetyczne w obrębie poszczególnych grup. Do oceny struktury kapitału badanych przedsiębiorstw przyjęto wskaźnik ogólnego zadłużenia, wskaźnik pokrycia aktywów trwałych kapitałami własnymi (obliczony jako relacja kapitałów własnych do aktywów trwałych) oraz inne wskaźniki zadłużenia: wskaźnik zadłużenia długoterminowego (obliczony jako relacja zobo- 
wiązań długoterminowych do kapitału własnego), wskaźnik udziału zobowiązań długoterminowych w zobowiązaniach ogółem (ustalony jako relacja zobowiązań długoterminowych do zobowiązań ogółem).

Do oceny rentowności przedsiębiorstwa posłużyły: wskaźnik rentowności kapitału własnego ROE (obliczony jako relacja zysku netto do kapitałów własnych), wskaźnik rentowności aktywów ROA (obliczony jako relacja zysku netto do aktywów ogółem) oraz sprzedaży ROS (obliczony jako relacja zysku netto do przychodów ze sprzedaży) oraz wskaźnik rentowności operacyjnej sprzedaży ROS operacyjne (obliczony jako relacja zysku operacyjnego do przychodów ze sprzedaży).

Do badania zależności między zmiennymi zastosowano analizę korelacji Pearsona. Dane zaprezentowano w formie opisowej oraz graficznej.

\section{WYNIKI BADAŃ}

Na rysunku 1. zaprezentowano średnie wielkości wskaźnika ogólnego zadłużenia w lata 2011-2015 oraz w wyodrębnionych grupach przedsiębiorstw. Wskaźnik ogólnego zadłużenia stanowi jednocześnie odzwierciedlenie struktury kapitału badanych podmiotów.

W badanym okresie wskaźnik ogólnego zadłużenia wszystkich spółek sektora budowlanego w Polsce wyniósł średnio 58,22\%. Złota reguła finansowania wskazuje, iż wskaźnik ten powinien kształtować się na poziomie 50\%. Według

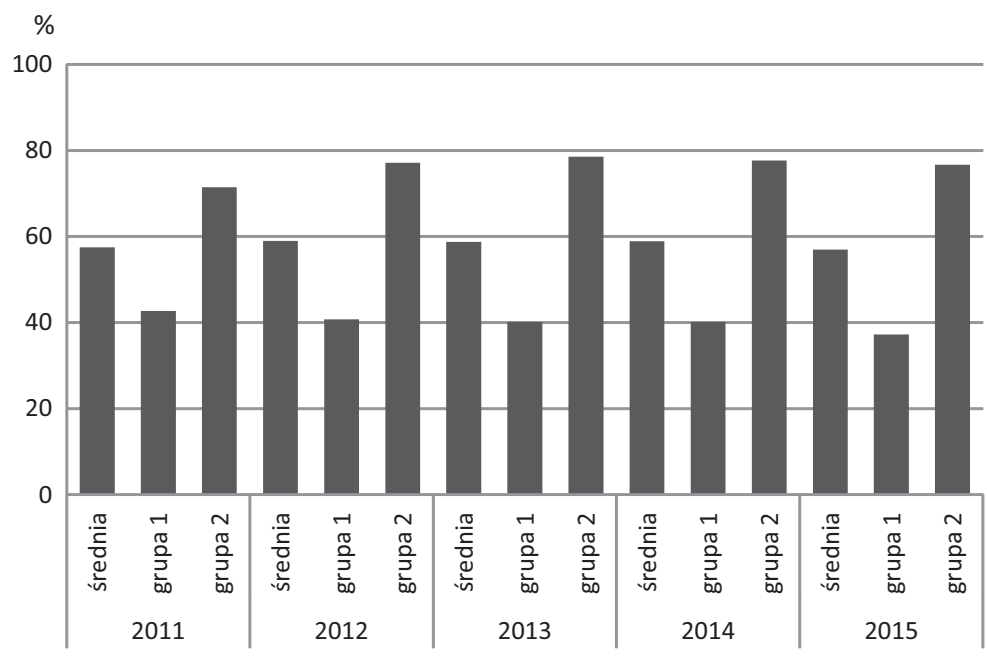

RYSUNEK. 1. Wskaźnik ogólnego zadłużenia przedsiębiorstw branży budowlanej w latach 2011-2015

Źródło: Opracowanie własne. 
standardów zachodnich uznaje się, że w przedsiębiorstwach, w których została zachowana równowaga między kapitałem obcym a kapitałem własnym, wskaźnik ogólnego zadłużenia powinien kształtować się na poziomie od 57 do 67\% [Sierpińska, Jachna 2007, s. 89]. Zadłużenie ogółem sektora utrzymywało się w latach 2011-2015 na względnie stałym poziomie. Największy jego spadek odnotowano w 2015 roku. Wielkość wskaźnika zmniejszyła się w stosunku do roku poprzedniego o prawie 2 p.p.

W pierwszej grupie badanych spółek średnia wielkość wskaźnika ogólnego zadłużenia w latach 2011-2015 wyniosła 40,2\%, czyli była o 15 p.p. niższa niż dla całego sektora budowlanego. Najniższy poziom wskaźnik osiągnął w 2015 roku $(37,23 \%)$. W drugiej grupie średnia wielkość wskaźnika w całym badanym okresie wyniosła 76,32\%. W latach 2011-2013 obserwowano jej wzrost, a od 2014 roku wielkość wskaźnika ulegała obniżeniu. W 2015 roku wskaźnik osiągnął najniższy poziom w całym badanym okresie (76,73\%). Oznacza to, że w 2015 roku majątek przedsiębiorstw budowlanych był w najmniejszym stopniu finansowany kapitałami obcymi. Wysoka wielkość wskaźnika (powyżej 50\%) informuje o dużym uzależnieniu finansowym przedsiębiorstwa, gdyż jego aktywa są w większym stopniu finansowane ze źródeł obcych [Nowak 2017, s. 268].

Rysunek 2. obrazuje kształtowanie się wskaźnika zadłużenia długoterminowego w branży budowlanej w latach 2011-2015.

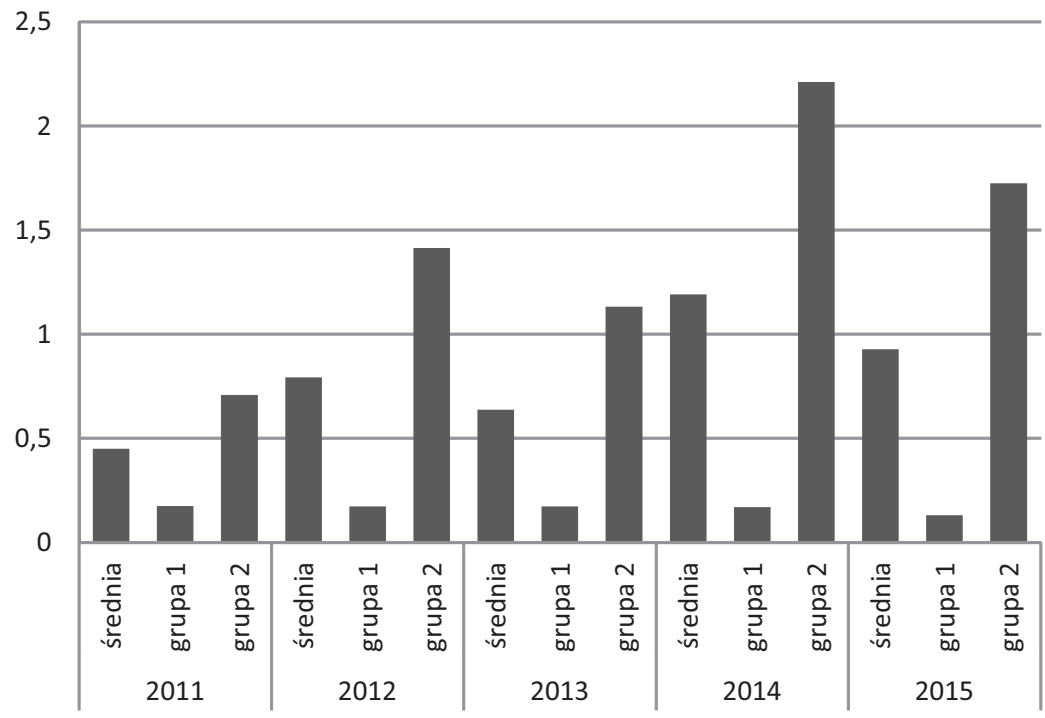

RYSUNEK 2. Wskaźnik zadłużenia długoterminowego przedsiębiorstw branży budowlanej w latach 2011-2015 ogółem i w podziale na grupy

Źródło: Opracowanie własne. 
W latach 2011-2015 wskaźnik zadłużenia długoterminowego dla wszystkich przedsiębiorstw branży budowlanej wyniósł średnio 0,80. W całym badanym okresie wielkości wskaźnika ulegały znacznym wahaniom. W 2012 roku wskaźnik znacząco zwiększył się w stosunku do 2011 roku, zaś w 2013 roku zmniejszył o 0,15 punktu w odniesieniu do roku poprzedniego. W 2014 roku osiągnął on wielkość 1,19. Zakładając, że racjonalny poziom wskaźnika długu powinien mieścić się w przedziale 0,5-1,0 można uznać, że w omawianym roku sektor budowlany w Polsce był nadmiernie zadłużony. W 2015 roku zdecydowanie zmniejszyło się obciążenie kapitałów własnych zobowiązaniami długoterminowymi w stosunku do roku poprzedniego. Była to sytuacja korzystna - oznacza, że zadłużenie sektora budowlanego uległo obniżeniu.

Przedsiębiorstwa zaklasyfikowane do pierwszej grupy w całym badanym okresie osiągały bardzo niskie wielkości wskaźnika zadłużenia długoterminowego. Średnio wskaźnik ten wyniósł 0,16. W latach 2011-2015 wskaźnik osiągał wielkości powyżej 0,17. W roku 2015 jego wielkość dla badanej grupy osiągnęła bardzo niski poziom i wyniosła jedynie 0,13. W grupie drugiej średnia wielkość wskaźnika zadłużenia długoterminowego dla badanego okresu wyniosła 1,44. W 2011 roku poziom wskaźnika był najniższy. Wyniósł on jedynie 0,71. W kolejnych latach poziom wskaźnika osiągał wielkości powyżej 1,0, czyli w omawianym okresie zobowiązania długoterminowe były wyższe od kapitałów własnych, co oznacza wysokie zadłużenie badanych przedsiębiorstw. Może to sygnalizować zwiększone ryzyko niewypłacalności badanych podmiotów, a tym samym utrudniać pozyskiwanie nowych kredytów oraz emisję obligacji. Najwyższy poziom wskaźnik zadłużenia długoterminowego osiągnął w 2014 roku $(2,20)$.

Poziom wskaźnika zadłużenia długoterminowego był bardzo zróżnicowany w obrębie badanych grup przedsiębiorstw. Przedsiębiorstwa zaklasyfikowane do pierwszej grupy (mniej zadłużone) wykazywały znacznie niższy poziom omawianego wskaźnika. Przedsiębiorstwa należące do drugiej grupy (bardziej zadłużone) wykazywały większe obciążenie kapitału własnego zobowiązaniami długoterminowymi. Wskaźnik zadłużenia długoterminowego jest uzupełnieniem wskaźnika ogólnego zadłużenia. Jest pożądane, aby wskaźnik zadłużenia długoterminowego przybierał wielkości zbliżone do poziomu wskaźnika ogólnego zadłużenia, bowiem wówczas udział zobowiązań o dłuższym terminie wymagalności w całości zobowiązań przedsiębiorstwa jest wysoki. Sprzyja to stabilności finansowej przedsiębiorstwa [Nowak 2017, s. 268].

Rysunek 3 przedstawia wielkość udziału zobowiązań długoterminowych w zobowiązaniach ogółem i w analizowanych grupach w latach 2011-2015. Poziom wskaźnika nie był wysoki. Średni dla całego sektora budowlanego wskaźnik udziału zobowiązań długoterminowych w zobowiązaniach ogółem w badanym okresie wyniósł 25,48\%. Oznacza to duży udział zobowiązań krótkoterminowych 
w zobowiązaniach ogółem. Sytuacja taka nie jest korzystna dla przedsiębiorstwa, bowiem zbyt duża koncentracja zobowiązań krótkoterminowych może prowadzić do utraty płynności finansowej, narastania długów w wyniku kumulowania się odsetek oraz utraty zdolności do utrzymania się na rynku [Sierpińska, Jachna 2004, s. 168], a w konsekwencji nawet do upadłości podmiotu. W latach 2011-2013 wielkość wskaźnika wzrosła z 23\% w 2011 roku do 26,17\% w 2013 roku. Od 2014 roku sektor budowlany odnotowywał powolne zmniejszanie wielkości badanego wskaźnika. Sytuacja uległa zmianie w 2015 roku, w którym wielkość wskaźnika wzrosła w stosunku do roku poprzedniego o niespełna 2 p.p. Oznacza to zmniejszenie udziału zobowiązań krótkoterminowych w łącznej sumie zobowiązań sektora budowlanego, a tym samym powoduje redukcję ryzyka niewypłacalności badanych spółek.

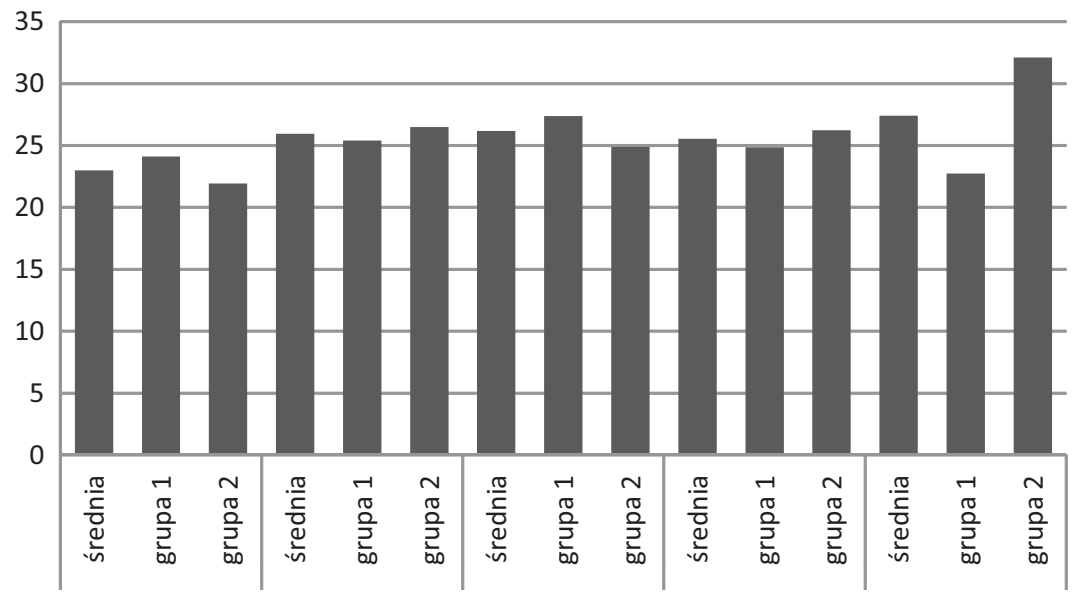

RYSUNEK 3. Wskaźnik udziału zobowiązań długoterminowych w zobowiąza-niach ogółem przedsiębiorstw branży budowlanej w podziale na grupy (\%)

Źródło: Opracowanie własne.

W przedsiębiorstwach pierwszej grupy wskaźnik udziału zobowiązań długoterminowych w zobowiązaniach ogółem wyniósł średnio 24,9\%. Poziom wskaźnika był zatem bardzo zbliżony do wielkości wskaźnika dla całego sektora i w całym badanym okresie ulegał nieznacznym zmianom. W 2015 roku jego poziom istotnie się obniżył do 22,73\% z 24,86\% w 2014 roku W drugiej grupie omawiany wskaźnik wyniósł średnio 26,33\% w analizowanym okresie. Był zatem wyższy od średniej wielkości wskaźnika w pierwszej grupie o 1,43 p.p. oraz o 0,85 p.p. od średniej dla całego sektora. Oznacza to, że przedsiębiorstwa drugiej grupy miały nieznacznie niższy udział zobowiązań krótkoterminowych w ogólnej sumie zobowiązań, a zatem narażone były w mniejszym stopniu na utratę płynności. 
Na rysunku 4 zaprezentowano wyniki dotyczące pokrycia aktywów trwałych kapitałami własnymi przedsiębiorstw sektora budowlanego jako średnie wielkości dla wszystkich spółek w poszczególnych latach, a także w podziale na grupy przedsiębiorstw. Wskaźnik obrazuje udział kapitałów własnych w finansowaniu majątku trwałego. Im wyższa wielkość tego wskaźnika, tym bardziej wierzyciele mogą liczyć na odzyskanie swojego wkładu w spółkę w sytuacji ewentualnej likwidacji przedsiębiorstwa [Wyszkowska 2006, s. 565].

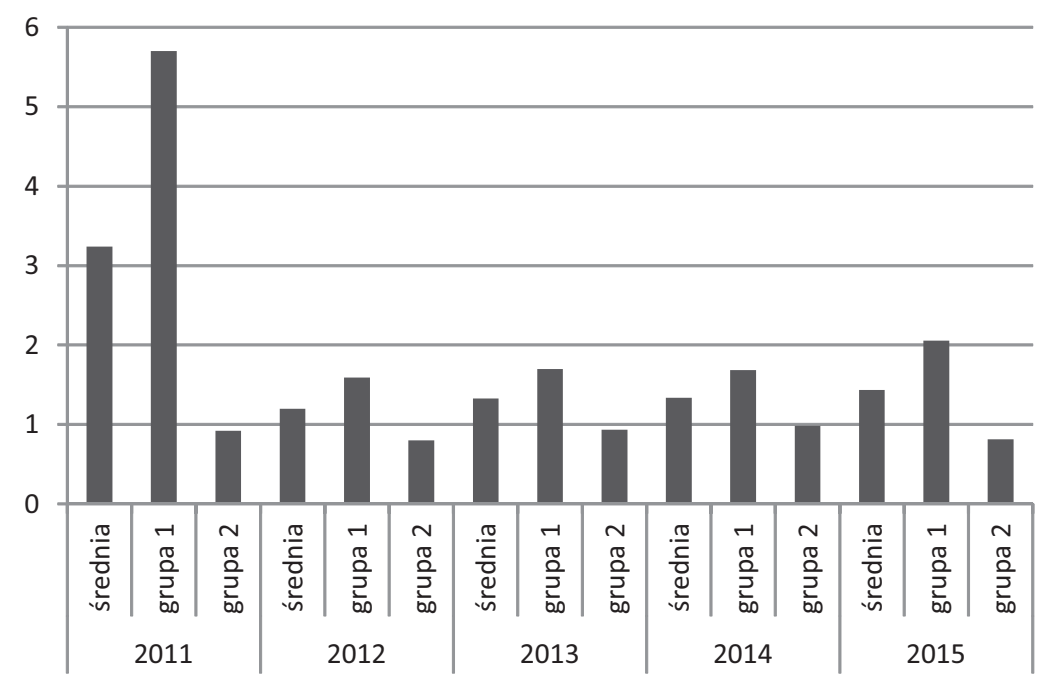

RYSUNEK 4. Wskaźnik pokrycia aktywów trwałych kapitałami własnymi przedsiębiorstw branży budowlanej w podziale na grupy

Źródło: Opracowanie własne.

Wskaźnik pokrycia aktywów trwałych kapitałami własnymi wyniósł w latach 2011-2012 średnio 1,71. W 2011 roku wielkość wskaźnika była najwyższa, osiągnęła poziom 3,24. W 2012 roku istotnie zmniejszyła się, aby w latach 2013-2015 wykazać się wzrost. Na podstawie rysunku 4. można stwierdzić, że największą wiarygodnością kredytową sektor budowlany charakteryzował się w 2011 roku, a najniższą w 2012 roku. Istotne jest to, że w żadnym z analizowanych lat wskaźnik udziału kapitałów własnych w finansowaniu majątku trwałego nie przyjął wielkości poniżej 1. Ujemny poziom wskaźnika oznacza, że część majątku jest finansowana przez kapitał obcy, co wskazuje na niekorzystną sytuację finansową spółki.

W 2011 roku w pierwszej grupie wskaźnik pokrycia aktywów trwałych kapitałami własnymi był najwyższy, osiągnął poziom 5,70, aby w roku następnym obniżyć się o ponad 4 punkty. Przez trzy kolejne lata wielkość wskaźnika wahała się nieznacznie. W żadnym z rozpatrywanych okresów nie osiągnęła poziomu po- 
niżej 1. W 2015 roku wskaźnik uległ znacznej poprawie. W drugiej grupie poziom wskaźnika wahał się w przedziale od 0,80 do 0,98. W każdym roku jego wielkość osiągała poziom poniżej 1. Średnia wielkość wskaźnika dla drugiej grupy w latach 2011-2015 wyniosła 0,89. A zatem wielkość wskaźnika była istotnie zróżnicowana między badanymi grupami przedsiębiorstw. W pierwszej grupie wskaźnik osiągał znacznie wyższe wielkości w każdym roku, co oznacza, że wiarygodność kredytowa spółek z drugiej grupy była znacznie niższa niż w pierwszej grupie. Aktywa trwałe uznawane są za obciążone wysokim ryzykiem. Są one majątkiem o niskim stopniu płynności, a przez to mało elastycznie reagują na zmiany na rynku. Pokrycie ich w co najmniej 100\% kapitałami własnymi jest sytuacją pożądaną, zwiększa to m.in. wiarygodność kredytową podmiotów.

Rysunek 5 ilustruje poziom rentowności i deficytowości badanych spółek sektora budowlanego w latach 2011-2015. Dla badanego okresu obliczono średni dla sektora wskaźnik rentowności kapitału własnego (ROE), wskaźnik rentowności aktywów (ROA) oraz wskaźnik rentowności sprzedaży (ROS) i wskaźnik rentowności operacyjnej sprzedaży (ROS operacyjne).

Średnia wielkość wskaźnika deficytowości kapitału własnego w badanym okresie wyniosła -5,47\%. W latach 2011-2013 wskaźnik obniżał się. Najniższy poziom -17,06\% osiągnął w 2013 roku. Ujemne wielkości wskaźnika rentowności kapitału własnego oznaczają, że kapitał ten pracuje w sposób nieefektywny. Od 2014 roku wielkość wskaźnika wzrastała. Odnotowano wzrost o 18,14 p.p w stosunku do roku poprzedniego. W 2015 roku wskaźnik ROE osiągnął najwyższy poziom $(11,30 \%)$.

Wskaźnik deficytowości aktywów w latach 2011-2015 przyjmował wielkość średnią na poziomie -0,42\%. W całym badanym okresie wskaźnik ulegał znacznym wahaniom. Najniższy poziom wskaźnika odnotowano w 2013 roku. Od tego roku wielkość wskaźnika wzrastała, aby w 2015 roku osiągnąć najwyższą wielkość. W 2015 roku wskaźnik wzrósł o 1,81 p.p. Niski poziom wskaźnika rentowności aktywów branży budowlanej w badanym okresie wskazuje na mało efektywne zarządzanie aktywami przez badane podmioty. Im wyższa wielkość tego wskaźnika, tym sytuacja finansowana podmiotu jest korzystniejsza.

W latach 2011-2015 średni poziom wskaźnika deficytowości sprzedaży osiągnął poziom -0,53\%. Podobnie jak wielkości wskaźników rentowności kapitału własnego oraz aktywów, wielkość wskaźnika rentowności sprzedaży w latach 2011-2013 była ujemna, co odzwierciedla wysokość straty ponoszonej przez sektor w badanym okresie. Najniższy poziom wskaźnik ten osiągnął w 2012 roku. W 2014 roku jego wielkość zaczęła rosnąć. W 2015 roku wzrosła w stosunku do roku poprzedniego o 2,12 p.p. i osiągnęła wielkość najwyższą w badanym okresie. Oznacza to, że w omawianym roku sektor budowlany wygenerował najwyższe zyski ze sprzedaży. Uwzględniając jednak długość cyklu sprzedaży w tym sektorze należy stwierdzić, że poziom wskaźnika nie jest wysoki. 


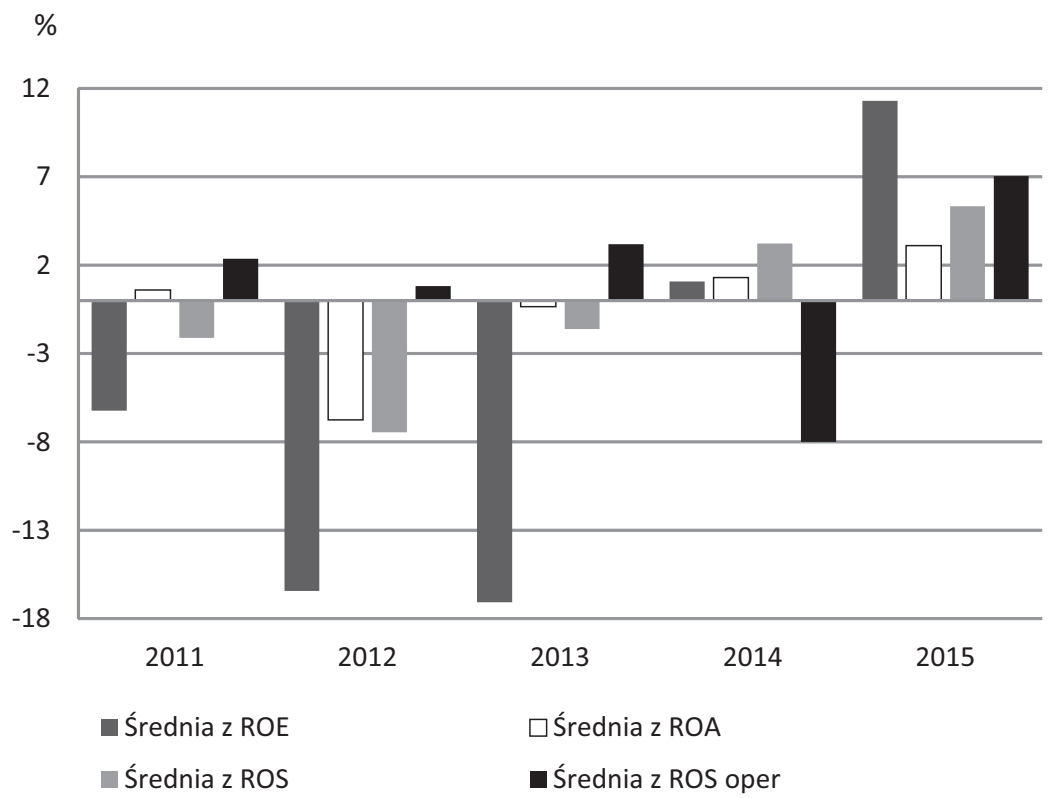

RYSUNEK 5. Wskaźniki rentowności/deficytowości kapitału własnego, aktywów oraz sprzedaży w badanych przedsiębiorstwach branży budowlanej (\%)

Źródło: Opracowanie własne.

Średnia wielkość wskaźnika rentowności operacyjnej sprzedaży w latach 2011-2015 wyniosła 1,08\%. Poziom wskaźnika ulegał znacznym wahaniom. W 2014 roku wskaźnik osiągnął wielkość ujemną i tym samym najniższy poziom w ciągu pięciu lat. W 2015 roku wzrósł w stosunku do roku poprzedniego o 15,03 p.p. i osiągnął poziom najwyższy w badanym okresie. W 2015 roku branża budowlana odnotowała istotną poprawę wielkości wszystkich wskaźników rentowności. Wskaźnik rentowności kapitału własnego osiągnął rekordową wielkość 11,3\%, wyższą w stosunku do roku poprzedniego o 10 p.p. Podobnie rentowność operacyjna sprzedaży - wzrosła w stosunku do 2014 roku o 15 p.p.. Nieznaczna poprawa wskaźników rentowności w 2014 roku oraz istotny wzrost ich wielkości w 2015 roku wynikają z poprawy ogólnej koniunktury polskiego sektora budownictwa. Jak bowiem wynika z raportów, branża budowlana w Polsce odnotowała w latach 2014-2015 nieznaczne ożywienie po okresie pogorszenia wyników w latach 2012-2013 [Raport Polskie... 2016].

Na rysunku 6. przedstawiono poziom wskaźników rentowności i deficytowości aktywów, kapitału własnego oraz sprzedaży dla przedsiębiorstw zaklasyfikowanych do grupy pierwszej (mniej zadłużonych).

Średnia wielkość wskaźnika rentowności aktywów w grupie przedsiębiorstw mniej zadłużonych wyniosła w badanym okresie 1,88\%. W 2011 roku wskaźnik 


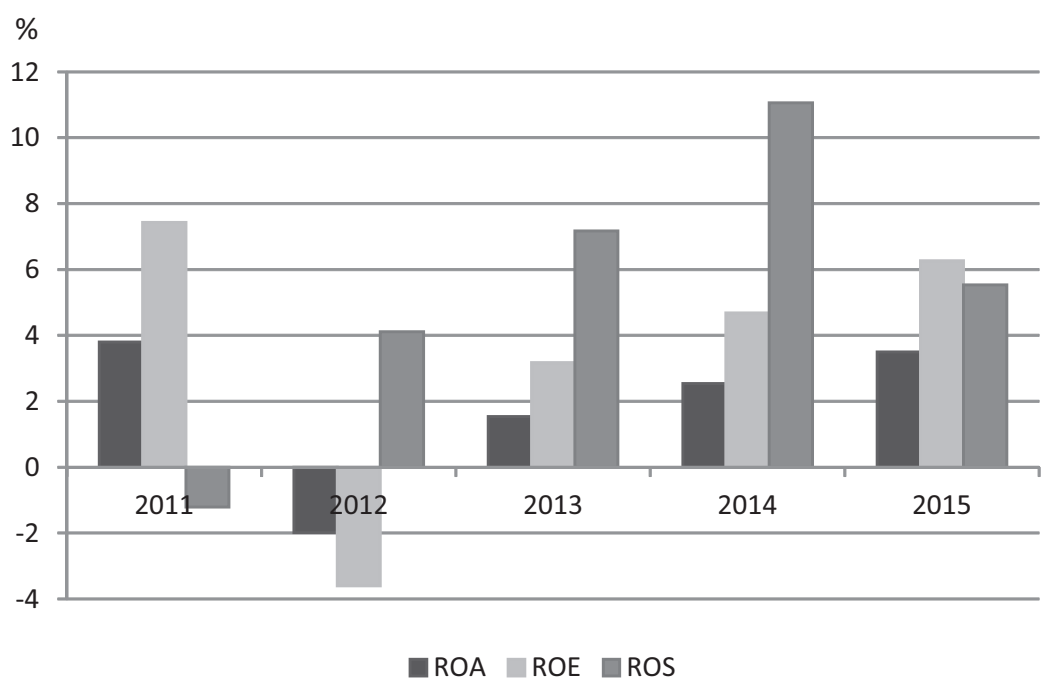

RYSUNEK 6. Wskaźniki rentowności/deficytowości kapitału własnego, aktywów oraz sprzedaży w grupie badanych przedsiębiorstw branży budowlanej o niższym poziomie zadłużenia

Źródło: Opracowanie własne.

osiągnął najwyższą wielkość. W roku następnym wskaźnik deficytowości aktywów wyniósł -1,99\%. Była to najniższa wielkość w całym badanym okresie. W latach 2013-2014 wskaźnik ROA wzrastał. Wysokie wielkości wskaźnika rentowności aktywów w tym okresie wskazują na efektywne zarządzanie aktywami przez badane spółki.

W latach 2011-2015 wskaźnik rentowności kapitału własnego wyniósł średnio 3,59\%. W 2011 roku wielkość wskaźnika była najwyższa, osiągnęła poziom 7,43\%, a w 2012 roku wskaźnik deficytowości wyniósł -3,60\%. Była to wielkość najniższa w całym badanym okresie. W latach 2013-2015 wielkość wskaźnika systematycznie wzrastała, osiągając odpowiednio wielkości 3,17\%, 4,68\% i 6,26\%. Wysoki poziom wskaźnika w tych latach świadczy o korzystnej sytuacji finansowej badanych spółek oraz większych korzyściach dla akcjonariuszy. Wyższa stopa zwrotu z kapitału własnego stwarza możliwość uzyskania wyższych dywidend i wyższego przyrostu wartości akcji [Sierpińska, Jachna 2004, s. 204].

Wskaźnik rentowności sprzedaży osiągnął średnią wielkość w badanych okresie 5,33\%. W 2011 roku wskaźnik deficytowości sprzedaży wyniósł -1,21\%. W latach 2012-2014 wielkość wskaźnika rosła i w 2014 roku osiągnął on najwyższy poziom (11,05\%). W 2015 roku poziom wskaźnika obniżył się o 5,52 p.p., nadal utrzymując się na bardzo wysokim poziomie. Oznacza to, że przedsiębiorstwa należące do grupy mniej zadłużonych generowały wysokie zyski ze sprzedaży. 
Rysunek 7 ilustruje poziom wskaźników rentowności oraz deficytowości aktywów, kapitału własnego i sprzedaży dla przedsiębiorstw branży budowlanej o wyższym poziomie ogólnego zadłużenia.

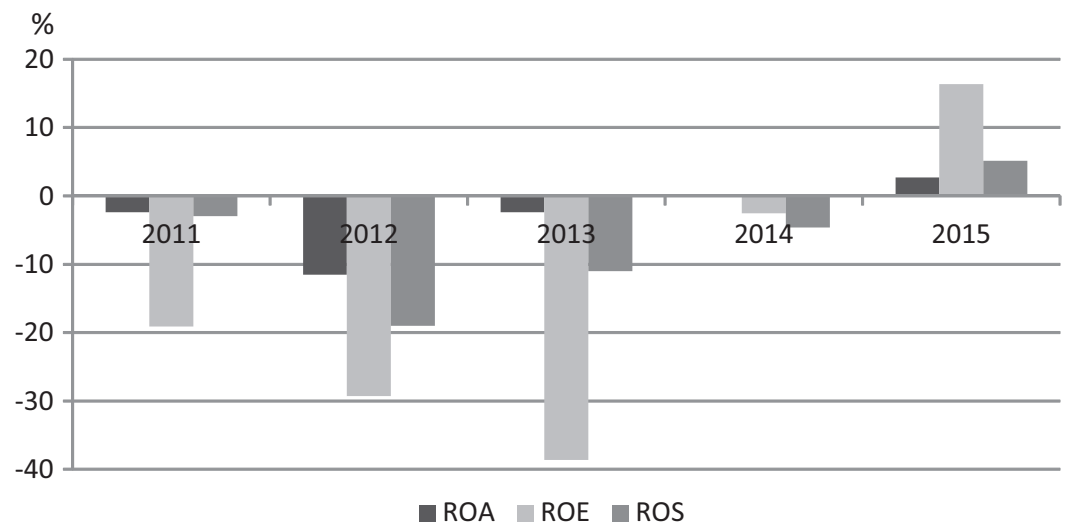

RYSUNEK 7. Wskaźnik rentowności/deficytowości kapitału własnego, aktywów oraz sprzedaży w grupie badanych przedsiębiorstw branży budowlanej o wyższym poziomie zadłużenia

Źródło: Opracowanie własne.

Wskaźnik deficytowości aktywów przedsiębiorstw bardziej zadłużonych w badanym okresie wyniósł -2,71\%. W 2012 roku wskaźnik osiągnął najniższy poziom -11,51\%. Od 2013 roku wielkość wskaźnika wzrastała. Wskaźnik ten przyjął wielkości dodatnie tylko w latach 2014-2015. Oznacza to bardzo nieefektywne zarządzanie aktywami oraz wysoce niekorzystną sytuację finansową badanych podmiotów.

Średnia wielkość wskaźnika deficytowości kapitału własnego w badanym okresie wyniosła -14,64\%. W latach 2011-2014 wskaźnik przyjmował wielkości ujemne. Najniższy poziom wskaźnika deficytowości finansowej odnotowano w 2013 roku $(-38,64 \%)$. Tak niski poziom wskazuje na ogromne straty generowane przez aktywa zaangażowane w działalność badanych spółek. W 2014 roku wielkość wskaźnika wzrosła o 36,12 p.p. w stosunku do roku poprzedniego, osiągając poziom -2,52\%. Wskaźnik rentowności aktywów w 2015 roku przyjął wielkość 16,33\%. Wzrósł w stosunku do roku 2014 o 18,86 p.p. Oznacza to, że jedynie w 2015 roku aktywa badanych przedsiębiorstw przynosiły zyski, czyli były zarządzane w sposób efektywny.

W latach 2011-2015 wielkość wskaźnika deficytowości sprzedaży wyniosła średnio -6,49\%. W 2012 roku wskaźnik osiągnął najniższy poziom w badanym okresie (-19,03\%). W latach 2013-2015 obserwowano wzrost wskaźnika i w 2015 roku przyjął o wielkość dodatnią na poziomie 5,14\%. Oznacza to, że 
w latach 2011-2015 sprzedaż w spółkach zaklasyfikowanych do grupy bardziej zadłużonych w sektorze budowlanym była nieopłacalna (generowała straty) i dopiero w 2015 roku sprzedaż zaczęła przynosić zyski. Rysunki 6. i 7. pokazują, że rentowność aktywów, kapitału własnego i sprzedaży była znacznie wyższa w przedsiębiorstwach pierwszej grupy (mniej zadłużonych). W tych podmiotach wskaźnik deficytowości aktywów i kapitału własnego przyjął wielkość ujemną tylko w 2012 roku. Spółki zaklasyfikowane do grupy o wyższym poziomie zadłużenia ogółem wykazywały bardzo niskie wielkości wskaźników deficytowości aktywów, kapitału własnego i sprzedaży. Sytuacja uległa zmianie w 2015 roku. Wszystkie wskaźniki osiągnęły wtedy wielkości dodatnie. Było to efektem poprawy ogólnej koniunktury gospodarczej oraz wyników finansowych przedsiębiorstw sektora budowlanego.

W celu określenia zależności pomiędzy strukturą kapitału badanych przedsiębiorstw sektora budowlanego a poziomem ich rentowności przeprowadzono analizę korelacji, obliczając współczynnik korelacji liniowej Pearsona. W tabeli 1. wyszczególniono współczynniki istotne z p<0,05, a prezentuje ona wielkości współczynnika korelacji wskaźnika ogólnego zadłużenia, zadłużenia długoterminowego oraz udziału zobowiązań długoterminowych w zobowiązaniach ogółem ze wskaźnikami rentowności aktywów, kapitału własnego oraz sprzedaży badanych przedsiębiorstw dla badanych przedsiębiorstw ogółem oraz wyodrębnionych grup przedsiębiorstw. W tabeli 1. podano poziomy istotności (p) dla poszczególnych współczynników korelacji.

Z przeprowadzonych badań wynika, że wystąpiła nieznaczna korelacja między wybranymi zmiennymi. Wskaźnik rentowności aktywów był ujemnie skorelowany (współczynnik korelacji na poziomie -0,21) ze wskaźnikiem ogólnego zadłużenia, wyrażającym jednocześnie strukturę kapitału badanych podmiotów. Oznacza to, że w miarę zwiększania ogólnego zadłużenia majątku obniża się rentowność aktywów w badanych przedsiębiorstwach. Wskaźnik rentowności kapitału własnego wykazał ujemną korelację ze wskaźnikiem zadłużenia długoterminowego. Współczynnik korelacji wyniósł -0,22. Wskaźnik rentowności operacyjnej nie wykazał istotnej korelacji z żadnym ze wskaźników zadłużenia. Wskaźnik rentowności operacyjnej sprzedaży jest dodatnio skorelowany ze wskaźnikiem udziału zobowiązań długoterminowych w zobowiązaniach ogółem. Oznacza to, iż wraz ze wzrostem udziału zobowiązań długoterminowych w zobowiązaniach ogółem wzrasta wskaźnik rentowności operacyjnej sprzedaży.

W pierwszej grupie badanych przedsiębiorstw branży budowlanej współczynniki korelacji pomiędzy wskaźnikami zadłużenia oraz rentowności utrzymywały się na bardzo niskim poziomie. Stwierdzono, że istotnie skorelowane były dwie badane zmienne. Pomiędzy wskaźnikiem udziału zobowiązań długoterminowych w zobowiązaniach ogółem a wskaźnikiem rentowności operacyjnej sprzedaży odnotowano dodatnią korelację na poziomie 0,23 . Oznacza to, że wraz ze wzro- 
TABELA 1. Współczynniki korelacji wskaźników zadłużenia i wskaźników rentowności/ deficytowości w badanych przedsiębiorstwach branży budowlanej

\begin{tabular}{|c|c|c|c|}
\hline Zmienna & $\begin{array}{l}\text { Wskaźnik } \\
\text { ogólnego } \\
\text { zadłużenia }\end{array}$ & $\begin{array}{l}\text { Wskaźnik zadłużenia } \\
\text { długoterminowego }\end{array}$ & $\begin{array}{c}\text { Wskaźnik udziału } \\
\text { zobowiązań długotermino- } \\
\text { wych w zobowiązaniach } \\
\text { ogółem }\end{array}$ \\
\hline \multicolumn{4}{|c|}{ Branża budowlana ogółem $(\mathrm{N}=156)$} \\
\hline ROA & $\begin{array}{c}-0,21 \\
p=0,000\end{array}$ & $\begin{array}{c}-0,04 \\
p=0,371\end{array}$ & $\begin{array}{c}0,01 \\
p=0,992\end{array}$ \\
\hline ROE & $\begin{array}{c}-0,12 \\
p=0,081\end{array}$ & $\begin{array}{c}-0,22 \\
p=0,003\end{array}$ & $\begin{array}{c}-0,10 \\
p=0,173\end{array}$ \\
\hline ROS & $\begin{array}{c}-0,04 \\
p=0,071\end{array}$ & $\begin{array}{c}0,01 \\
p=0,553\end{array}$ & $\begin{array}{c}0,04 \\
p=0,074\end{array}$ \\
\hline ROS operacyjne & $\begin{array}{c}-0,15 \\
p=0,062\end{array}$ & $\begin{array}{c}0,09 \\
p=0,269\end{array}$ & $\begin{array}{c}0,20 \\
p=0,011\end{array}$ \\
\hline \multicolumn{4}{|c|}{ Przedsiębiorstwa branży budowlanej o niższym poziomie zadłużenia (N=79) } \\
\hline ROA & $\begin{array}{c}-0,03 \\
p=0,569\end{array}$ & $\begin{array}{c}0,01 \\
p=0,600\end{array}$ & $\begin{array}{c}0,05 \\
p=0,485\end{array}$ \\
\hline ROE & $\begin{array}{c}-0,01 \\
p=0,259\end{array}$ & $\begin{array}{c}0,01 \\
p=0,505\end{array}$ & $\begin{array}{c}0,03 \\
p=0,686\end{array}$ \\
\hline ROS & $\begin{array}{c}-0,11 \\
p=0,051\end{array}$ & $\begin{array}{c}-0,02 \\
p=0,543\end{array}$ & $\begin{array}{c}0,07 \\
p=0,054\end{array}$ \\
\hline ROS operacyjne & $\begin{array}{c}-0,19 \\
p=0,112\end{array}$ & $\begin{array}{c}0,04 \\
p=0,687\end{array}$ & $\begin{array}{c}0,23 \\
p=0,001\end{array}$ \\
\hline \multicolumn{4}{|c|}{ Przedsiębiorstwa branży budowlanej o wyższym poziomie zadłużenia (N=77) } \\
\hline ROA & $\begin{array}{c}-0,45 \\
p=0,000\end{array}$ & $\begin{array}{c}-0,04 \\
p=0,739\end{array}$ & $\begin{array}{c}-0,05 \\
p=0,641\end{array}$ \\
\hline ROE & $\begin{array}{c}-0,06 \\
p=0,621\end{array}$ & $\begin{array}{c}-0,21 \\
p=0,059\end{array}$ & $\begin{array}{c}-0,18 \\
p=0,122\end{array}$ \\
\hline ROS & $\begin{array}{c}-0,39 \\
p=0,000\end{array}$ & $\begin{array}{c}-0,01 \\
p=0,992\end{array}$ & $\begin{array}{c}-0,13 \\
p=0,261\end{array}$ \\
\hline ROS operacyjne & $\begin{array}{c}-0,36 \\
p=0,001\end{array}$ & $\begin{array}{c}0,24 \\
p=0,033\end{array}$ & $\begin{array}{c}0,15 \\
p=0,201\end{array}$ \\
\hline
\end{tabular}

Źródło: opracowanie własne.

stem udziału zobowiązań długoterminowych w zobowiązaniach ogółem wzrasta wskaźnik rentowności operacyjnej sprzedaży. Korelacja pomiędzy omawianymi zmiennymi wystąpiła także w całej zbiorowości badanych spółek budowlanych. Poziom współczynnika korelacji w obu przypadkach kształtował się na bardzo zbliżonym poziomie. W drugiej grupie przedsiębiorstw był o 0,03 wyższy niż dla wszystkich badanych spółek. 
W drugiej grupie badanych przedsiębiorstw zaobserwowano istotną statystycznie korelację wskaźnika ogólnego zadłużenia ze wskaźnikami rentowności aktywów, sprzedaży oraz operacyjnej sprzedaży. Omawiany wskaźnik był ujemnie skorelowany (współczynnik korelacji na poziomie -0,45) ze wskaźnikiem rentowności aktywów. Oznacza to, że wraz ze wzrostem ogólnego zadłużenia majątku obniża się rentowność aktywów w badanych spółkach. Współczynnik korelacji wskaźnika ogólnego zadłużenia ze wskaźnikiem rentowności sprzedaży wyniósł -0,39, zaś ze wskaźnikiem rentowności operacyjnej sprzedaży -0,36. Wskaźnik zadłużenia długoterminowego wykazał korelację dodatnią ze wskaźnikiem rentowności operacyjnej sprzedaży. Oznacza to, że wraz ze wzrostem zadłużenia długoterminowego badanych przedsiębiorstw, wzrasta rentowność operacyjna sprzedaży. Współczynnik korelacji wyniósł 0,24. Wskaźnik udziału zobowiązań długoterminowych w zobowiązaniach ogółem nie jest istotnie statystycznie skorelowany z żadnym wskaźnikiem rentowności.

\section{PODSUMOWANIE}

W opracowaniu przedstawiono strukturę kapitału spółek sektora budowlanego oraz jej oddziaływanie na rentowność badanych podmiotów w obszarze sprzedaży, kapitałów własnych oraz aktywów. Na podstawie przeprowadzonych badań literaturowych i empirycznych sformułowano następujące wnioski:

1. W przedsiębiorstwach sektora budowlanego była zachowana równowaga pomiędzy kapitałem obcym a kapitałem własnym.

2. Spółki z wyższym poziomem zadłużenia ogółem cechowały się znacznie wyższym wskaźnikiem zadłużenia długoterminowego. Wysokie obciążenie kapitału własnego zobowiązaniami długoterminowymi oznacza większe ryzyko niewypłacalności. Może to stanowić przeszkodę w pozyskaniu nowych kredytów oraz przeprowadzeniu nowej emisji obligacji.

3. Badane spółki cechowały się dużym udziałem zobowiązań długoterminowych w zobowiązaniach ogółem. W drugiej grupie przedsiębiorstw (bardziej zadłużone) udział zobowiązań krótkoterminowych w ogólnej sumie zobowiązań był nieznacznie niższy.

4. W całym badanym okresie średnio branża budowlana wykazywała deficytowość aktywów, kapitału własnego oraz sprzedaży. Wskaźnik rentowności kapitału własnego oraz sprzedaży wykazały wielkości dodatnie tylko w latach 2014-2015. Poziom wskaźnika rentowności aktywów ulegał znacznym wahaniom. W 2015 roku nastąpiła duża poprawa wszystkich wskaźników, co wynikało z ogólnej poprawy koniunktury sektora budowlanego w Polsce.

5. Poziom wskaźników rentowności/ deficytowości w obrębie badanych grup był bardzo zróżnicowany. Spółki mniej zadłużone wykazywały rentowność 
aktywów, kapitału własnego oraz sprzedaży. Tylko w jednym roku wskaźniki były ujemne. Spółki w grupie o wyższym poziomie zadłużenia ogółem charakteryzowały się bardzo niskimi wskaźnikami deficytowości. W 2015 roku w obu badanych grupach nastąpiła poprawa. Wskaźniki rentowności osiągnęły wysoki poziom.

6. Przy ocenie zależności między strukturą kapitału a rentownością wszystkich badanych spółek sektora budowlanego nie stwierdzono istotnej korelacji pomiędzy badanymi zmiennymi. Wskaźnik ogólnego zadłużenia był istotnie ujemnie skorelowany ze wskaźnikiem rentowności aktywów. Wskaźnik zadłużenia długoterminowego był istotnie ujemnie skorelowany ze wskaźnikiem rentowności kapitału własnego. Wskaźnik udziału zobowiązań długoterminowych w zobowiązaniach ogółem wykazał istotną korelację ze wskaźnikiem operacyjnym rentowności sprzedaży.

7. W pierwszej grupie badanych przedsiębiorstw wykazano istotną statystycznie korelację między wskaźnikiem udziału zobowiązań długoterminowych w zobowiązaniach ogółem a wskaźnikiem operacyjnym rentowności sprzedaży. W grupie przedsiębiorstw o wyższym poziomie zadłużenia ogółem wystąpiła ujemna korelacja wskaźnika ogólnego zadłużenia ze wskaźnikami rentowności aktywów, kapitału własnego oraz sprzedaży. Oznacza to, że w miarę wzrostu poziomu zadłużenia przedsiębiorstwa maleje rentowność jego aktywów i sprzedaży.

\section{Spis literatury}

BARBURSKI J., 2016: Rozmiary działalności a struktura kapitałowo-majątkowa i rentowność przedsiębiorstw budowlanych notowanych na Giełdzie Papierów Wartościowych w Warszawie, Finanse, Rynki Finansowe, Ubezpieczenia, 79(1), s. 27-40.

BEREŻNICKA J., PAWLONKA T., 2014: Optimum kapitałowe w ocenie rentowności wybranych przedsiębiorstw branży mięsnej, Zagadnienia Ekonomiki Rolnej, 3, s. 136-153.

BIAŁEK-JAWORSKA A., NEHREBECKA N. 2015: Struktura kapitałowa przedsiębiorstw w świetle wyników badań, Zeszyty Teoretyczne Rachunkowości, 81, s. 29-51.

DONALDSON G., 1961: Corporate debt capacity: a study of corporate debt policy and the determination of corporate capacity, Harvard University, Graduate School of Business Administration, Boston.

DULINIEC A., 2001: Struktura i koszt kapitału w przedsiębiorstwie, Wydawnictwo Naukowe PWN, Warszawa.

DULINIEC A., 2007: Finansowanie przedsiębiorstwa, Polskie Wydawnictwo Ekonomiczne, Warszawa.

DULINIEC A., 2015: Wybór źródeł finansowania optymalna struktura kapitału w przedsiębiorstwie, Finanse, Rynki Finansowe, Ubezpieczenia, 74(2), s. 73-82. 
FRANC J., 2003: Struktura kapitału a procesy rozwojowe przedsiębiorstw rolniczych, Wydawnictwo SGGW, Warszawa.

GAJDKA J., 2002: Teorie struktury kapitału i ich aplikacja w warunkach polskich, Wydawnictwo Uniwersytetu Łódzkiego, Łódź.

JERZEMOWSKA M., HAJDUK A., 2015: Wpływ rentowności przedsiębiorstwa na strukturę kapitału na przykładzie spółek akcyjnych notowanych na Giełdzie Papierów Wartościowych w Warszawie, Zeszyty Naukowe Uniwersytetu Ekonomicznego w Krakowie, nr 2 (938), s. 45-57.

MĄDRA M., 2008: Struktura kapitału oraz uwarunkowania jej kształtowania w gospodarstwach rolniczych, Equilibrium, 1(2), s. 171-182.

MODIGLIANI F., MILLER M.H., 1958: The cost of capital, corporation finance and the theory of investment, American Economic Review, 48(3), s. 261-297.

NAWROT W., 2007: Struktura finansowania przedsiębiorstw w Polsce na tle badań międzynarodowych, „Gospodarka Narodowa”, 7-8, s. 19-42.

NOWAK E., 2017: Analiza sprawozdań finansowych, Polskie Wydawnictwo Ekonomiczne, Warszawa.

PAWLONKA T.A., 2016: Weryfikacja zależności wynikających z wybranych teorii struktury kapitału na przykładzie przedsiębiorstw branży mięsnej w Polsce, Wydawnictwo Wieś Jutra, Warszawa.

Raport Polskie spółki budowlane 2013- kluczowi gracze, perspektywy rozwoju i dywersyfikacji, https://www2.deloitte.com/pl/pl/pages/real-estate0/articles/Raport-PolskieSpolki-Budowlane-2013.html (13.03.2017 r.).

Raport Polskie spółki budowlane 2015 - najważniejsi gracze, kluczowe czynniki wzrostu i perspektywy rozwoju branży, https://www2.deloitte.com/content/dam/ Deloitte/ pl/Documents/Reports/pl_Polskie_spolki_budowlane_2 (13.03.2017 r.).

Raport Polskie spółki budowlane 2016 - najważniejsi gracze, kluczowe czynniki wzrostu i perspektywy rozwoju branży, https://www2.deloitte.com/pl/pl/pages/real-estate0/ articles/polskie-spolki-budowlane-raport-2016.html (13.03.2017 r.).

ROSS S. A., 1977: The Determination of Financial Structure: The Incentive-Signalling Approach, w: The Bell Journal of Economics, 1(8), 23-40.

SAJNÓG A., 2016: Zarządzanie kapitałem własnym a rentowność giełdowych spółek notowanych na GPW we Frankfurcie nad Menem i GPW w Warszawie, Acta Universitatis Lodziensis Folia Oeconomica, 4 (324), s. 89-108.

SIERPIŃSKA M., JACHNA T., 2004: Ocena przedsiębiorstwa według standardów światowych, Wydawnictwo Naukowe PWN, Warszawa.

SIERPIŃSKA M., Jachna T., 2007: Metody podejmowania decyzji finansowych, Wydawnictwo Naukowe PWN, Warszawa.

WYSZKOWSKA Z., 2006: Kapitał finansowy w przedsiębiorstwach, Nierówności społeczne a Wzrost Gospodarczy, nr 9, Problemy globalizacji i regionalizacji, cz. 2, s. 557-566. 


\title{
THE CAPITAL STRUCTURE VERSUS PROFITABILITY OF CAPITAL COMPANIES - THE EXAMPLE OF CONSTRUCTION SECTOR
}

\begin{abstract}
The aim of the research was to identify a relationship between the participation of liabilities in the debt structure and the level of profitability. The survey was conducted on the construction companies listed on the Warsaw Stock Exchange and relies on data for 2011-2015. Companies with a lower level of debt showed no statistically significant correlation between debt ratios and profitability of companies. In the group of companies with a higher level of debt there were statistically significant correlation between the debt ratio and the return on assets, the return on sales and the operating margin.
\end{abstract}

Key words: capital structure, profitability, construction companies, capital market 
